This item was submitted to Loughborough's Research Repository by the author.

Items in Figshare are protected by copyright, with all rights reserved, unless otherwise indicated.

\title{
Effective water safety management of piped water networks in low-income
} urban settlements

PLEASE CITE THE PUBLISHED VERSION

http://www.iwaponline.com/washdev/up/washdev2013105.htm

PUBLISHER

(C) IWA Publishing

VERSION

AM (Accepted Manuscript)

LICENCE

CC BY-NC-ND 4.0

REPOSITORY RECORD

Kayaga, Sam. 2019. "Effective Water Safety Management of Piped Water Networks in Low-income Urban Settlements”. figshare. https://hdl.handle.net/2134/12958. 
This item was submitted to Loughborough's Institutional Repository (https://dspace.lboro.ac.uk/) by the author and is made available under the following Creative Commons Licence conditions.

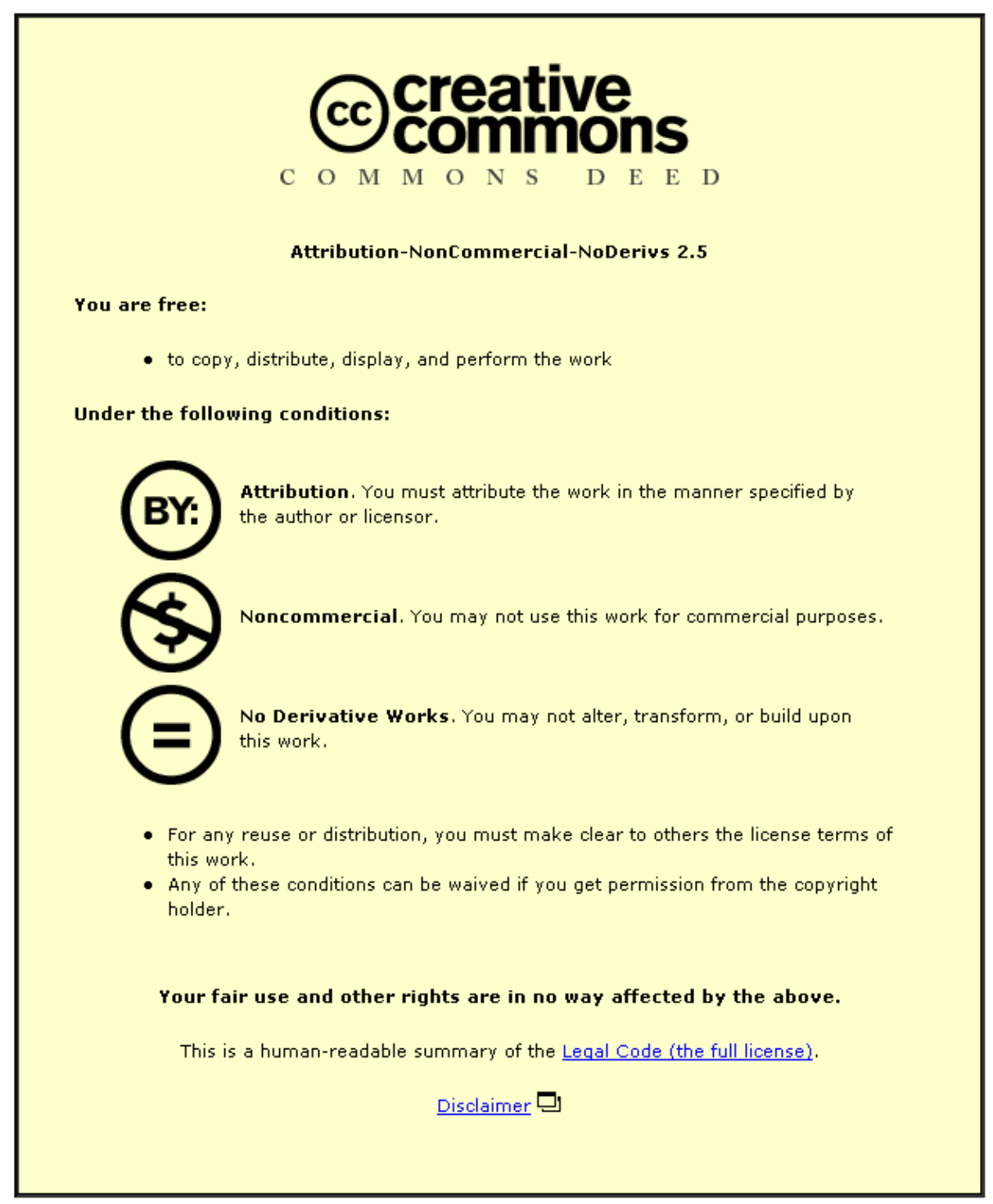

For the full text of this licence, please go to: http://creativecommons.org/licenses/by-nc-nd/2.5/ 


\title{
Effective Water Safety Management of Piped Water Networks in Low-income Urban Settlements
}

\section{Sam Kayaga}

Senior Lecturer/Programme Manager, Water, Engineering and Development Centre (WEDC), School of Civil and Building Engineering, Loughborough University, Leicestershire LE11 3TU, UK. s.m.kayaga@lboro.ac.uk

\begin{abstract}
Spiralling low-income settlements are a big challenge to urban water utilities of developing countries. To extend and maintain water services to these settlements, urban water utilities need to develop innovative solutions for overcoming various physical/technical, institutional, structural/legal and financial/economic constraints associated with these informal areas. This paper draws from documented pilot projects of implementing community-managed Water Safety Plans (WSPs) in various developing countries, and synthesises necessary ingredients for effective implementation of WSPs in low-income urban settlements. Urban water utilities need to partner with community members, but the former should keep a facilitating/overseeing role, given the overly technical nature of WSPs. The terms of the partnership should be mutually agreed and well documented; the utility should allow full participation of the relevant community members in the overall Operation and Maintenance (O\&M) plan for the low-income settlement, in order to enhance community ownership of the water supply system, and continuously develop the capacity of relevant community members. The relevant community members should be facilitated, through participatory approaches, to develop bespoke community-based WSPs along with simple monitoring tools. Implementing community-managed WSPs will be easier and more effective if O\&M systems and community management approaches are already institutionalised within the water utility.
\end{abstract}


Keywords | community participation, low-income urban settlements, operation and maintenance, piped water supply system, water safety management

\section{INTRODUCTION}

Urban water utilities in developing countries face various challenges in the external environment in which they operate. One of the major challenges is the rate at which lowincome settlements are expanding in the cities they serve. It is estimated that to-date, about one-sixth of the world urban population (about 1.15 billion $\left[10^{9}\right]$ ) live in low-income settlements, sometimes referred to as slums, and, if the trend remains unchecked, the number will rise to about 2 billion $\left(10^{9}\right.$ ) people by 2040 (UN-HABITAT 2010). UN-HABITAT (2003) defines a slum household as a group of individuals living under the same roof, in deprivation of basic infrastructure services such as basic piped water services, improved sanitation, sufficient living area, and security of tenure. It is estimated that about $60 \%$ of Africa's urban population, the world's fastest urbanising region, live in housing with at least one of the four defining characteristics of slums (Water and Sanitation Program 2009).

Most urban poor people do not have access to piped water and obtain water for their livelihoods from vendors, often at a higher price. Hence, the quantities of water obtained are usually inadequate and of questionable quality, which has negative socio-economic impacts on the households. Examples of the negative impacts arising from poor health include increased costs of medication, reduced productive time, and low school attendance. For a few poor households who are connected onto the distribution network, they will most likely be the last in line to get piped water services and/or will most likely receive intermittent supplies, with low service quality, which will be susceptible to water contamination (McIntosh 2003). Several scholars have shown the link between water supply and the 
health/welfare of people (e.g. Esrey 1996; Waite \& Ronche 2003), which in turn, increases urban poverty. Key characteristics of the low-income settlements that create barriers to water service delivery are irregular and undefined land tenure, high population density and unplanned physical layout (Water and Sanitation Program 2009).

The barriers to providing services to the urban poor may further be categorised as (i) physical/technical - difficult sites and hydro-geological terrains, where the poor usually tend to settle due to economic reasons, which require unconventional service delivery technologies (ii) economic and financial constraints - high costs of water and sanitation services, more specifically the high start-up costs for connection onto networked services; (iii) institutional constraints - the low institutional capacity of the utilities to cope with the complexities associated with servicing low-income urban settlements, e.g. the capability to relate with members of the local community and manage beneficial relationships with them; and (iv) structural/legal constraints - how low-income settlements are not prioritised under official definition of city boundaries, city planning approaches and legalisation/property rights in many cities of developing countries (Solo et al. 1993).

In most cities of developing countries, such low-income settlements are labelled as illegal, and often, because of this, the water utilities are not obliged to extend piped water services to these areas. Also, public water utilities do not have the creativity and innovativeness required to overcome the barriers of providing services to these low-income, unplanned settlements (Sansom \& Bos 2008). Most professionals employed by the water utilities are normally graduates in the physical sciences, who have acquired knowledge and skills in the 'hardware' aspects of providing water and sanitation services. Providing services to these low-income settlements also requires 'software’ skills such as social marketing, participatory approaches, 
livelihoods approaches, and hygiene education. As a result, most public water utilities cannot, by themselves, provide adequate levels of service to low-income settlements in the urban areas (Kayaga 2009). Water safety management in the low-income settlements is even more complex, as these settlements are usually unplanned and carry the biggest burden arising from low water quality and recontamination of piped water supplies in the distribution network. This is mainly because of the existing poor environmental sanitary conditions that are conducive for recontamination (Vairavamoorthy et al. 2006; Thompson \& Majam 2009).

Documented experience on the implementation of Water Safety Plans (WSPs) has been mainly about water distribution systems managed by water utilities, mostly in the developed region of the world (Mahmud et al. 2007). Currently, there is limited documented literature on the implementation of WSPs for small piped distribution systems, and less so for lowincome urban settlements. However, a common feature for most small water supply systems, regardless of the technology being used, is that the operation and maintenance is usually performed by members of the community (World Health Organisation [WHO] 2005). This paper reviews the international literature, and draws key learning points on how WSPs could effectively be implemented for piped water distribution systems in low-income urban settlements.

\section{METHODS}

The objective of this desk study was to review international literature on water safety management in low-income urban settlements. In the study, literature was reviewed and the key findings extracted, to identify good practices for the benefit of practitioners and policy makers in developing countries. The internet was used to search electronic databases using key words (i.e. water safety plans, urban poor, low-income settlements, urban water supply, 
water distribution, operation and maintenance) and their combinations. Databases of organisations known to disseminate knowledge and information on the topics were specifically consulted. Examples of these are the international Water, Engineering and Development Centre (WEDC) Conferences (for the period 2002-2011), the World Bank, IRC International Water and Sanitation Centre, and the Water and Sanitation Programme.

The sources of information were individually evaluated, to sort out those that significantly deal with the study areas, and the relevant information was recorded in an electronic coding document, in the form of an Excel sheet. These were subsequently analysed and are hereby presented conceptually, categorised according to important operational aspects.

\section{KEY INGREDIENTS FOR EFFECTIVE COMMUNITY-MANAGED WSPS}

\section{Water-Safety Plans - A component of the operations and maintenance system}

Water utilities are required to provide an acceptable level of service to their customers, in terms of drinking water quality and quantity. A water utility should have an effective operation and maintenance (O\&M) system in order to ensure that potable water in adequate quantities is produced and distributed to the customers. Operation may be defined as everyday running and correct handling of water supply system elements in order to convey safe drinking water to the users, and ensure long component life; while maintenance refers to activities carried out to sustain the water supply in a proper working condition, which could be preventive, corrective or crisis maintenance (Davis \& Brikke 1995). An effective O\&M system for the water distribution network will minimise deterioration of the water quality and physical water losses. 
The deterioration of water quality in the water distribution network may be as a result of ingress into the network, in-pipe processes, and/or pipe corrosion. An effective O\&M system for the water distribution network will ensure the network’s physical integrity (i.e. providing a physical barrier against external contamination); hydraulic integrity (i.e. maintaining adequate water pressures which minimise the risks of ingress into the pipe, and reduce sedimentation); and water quality integrity (i.e. preventing deterioration of water quality such as through biofilm growth, internal corrosion and leaching from pipe material) (Alegre et al. 2010). Since 2004, the World Health Organisation (WHO) has moved away from overreliance on the traditional water quality and safety management approach of end-product testing to a risk assessment and management approach to water quality management, and recommends the implementation of Water Safety Plans (WHO 2004, 2005; Howard et al. 2005).

Water Safety Plans (WSPs) may therefore be considered as a component of the overall organisational O\&M system that shifts the focus from end-of-pipe testing to improved operational management, which provides means of prioritising improvement programmes based on health outcomes (Government of India 2011). Various case studies in the developed regions of the world have shown that there is a strong link between poor O\&M practices and incidences of poor water, with severe water effects (Jayaratne 2008). WSPs involve the development of (or revision of existing) standard and emergency operating procedures. This process will easier be achieved if good O\&M practices are already institutionalised within the organisation (Parkinson 2010). In fact, WaterAid Bangladesh, after a series of pilot projects, had to eventually incorporate WSP activities within the regular O\&M activities under their Advancing Sustainable Environmental Health (ASEH) project, to avoid creating unnecessary extra burden to communities implementing WSPs (Tearfund 2011). As part of the process of 
identifying hazards and developing control measures, utility staff will usually have to identify gaps in operational procedures and routine/emergency maintenance, which may sometimes require upgrading the infrastructure, so as to improve the O\&M systems (Jayaratne 2008; Parkinson 2010).

\section{Involving communities in WSPs}

There is a strong justification for implementing WSPs in small scale piped distribution systems in low-income urban settlements mainly because the developments in these settlements are unplanned, which makes it difficult to locate and secure water supply mains and control activities in the catchment area (Thompson \& Majam 2009). As discussed in the introductory section, most urban water utilities may not, on their own, effectively implement WSPs given their inadequate levels of 'software' skills, which are necessary for coping with this level of complexity. In many developing countries, community participation has been embraced as a pragmatic response to weaknesses in public service provision, and community management is a central component of many water and sanitation sector policies (WaterAid 2011). However, the community management model has not always resulted in sustainable water services in some contexts of low-income countries (Harvey \& Reed 2007).

Various studies have shown that one of the key factors for sustainable community-managed water supply is on-going support from an overseeing institution (WaterAid 2011). For water service provision to low-income urban settlements, water utilities need to provide encouragement and motivation, monitoring, participatory planning, capacity building, and specialist technical assistance (Harvey \& Reed 2007). This support is more critical for implementing WSPs in water distribution systems in the low-income urban settlements, where community members have low technical skills (Mahmud et al. 2007). There is need to 
carry out on-going capacity development at both the operators’ and household levels (Tearfund 2011).

For WSPs to be effective, members of the community should be educated on all processes in the water cycle, and how the water supply can be made safe. Through health education and hygiene promotion, the users will be made aware of the consequences of drinking contaminated water, so that they can collectively work towards having a safe water supply (Tearfund 2011). A study carried out with several community-managed water schemes in Bangladesh showed that hygiene awareness was a prerequisite for effective WSPs (Mahmud et al. 2007). For instance, at the time of implementing WSPs in urban areas of Uganda (20022005), a study carried out in Kampala, the capital city, found that most residents of lowincome settlements suspected piped water to be contaminated, and boiled water for their household use. However, most respondents perceived water quality in terms of only colour and turbidity. Hence, National Water and Sewerage Corporation (NWSC), the Ugandan urban water utility opted to carry out a health and hygiene education, prior to introducing WSPs in the low-income settlements (Godfrey \& Howard 2005a, 2005b).

The water utility also needs to provide a higher level of capacity development to the caretakers and members of the local water committees, so as to provide them with specific skills for implementing various tasks pertaining to WSPs in the low income settlements. The tasks for WSPs in low-income settlements should be as simplified as possible, for the benefit of the local operators, given the low level of skills amongst the community members (Mahmud et al. 2007; Tearfund 2011). To simplify the processes as much as possible, WHO recommends that the development of WSPs for small systems should focus on the control of microbial quality and, particularly, pathogens arising out of faecal contamination, which will 
be most significant in shallow aquifers. Assessment of risks caused by chemicals such as arsenic, nitrate and fluoride in the small water supplies would better be addressed at the design stage, rather than through operational controls (WHO 2005).

Another important factor for effectiveness of community-managed WSPs is the level of community participation and ownership of the programme. A study carried out in 121 community-managed water supply projects (Narayan 1995 reported in WaterAid 2011) showed that the degree of participation was more significant than any other factor in achieving functioning water systems. This proposition is supported by a more recent evaluation of four pro-poor urban water supply projects funded by the World Bank in three African countries, which found out that there were more effective pro-poor outcomes in projects where there were higher levels of community participation, starting right from project inception, design, construction, O\&M, and monitoring/evaluation (Uwejamomere \& Northover 2012). An earlier study carried out in Dhaka, Bangladesh came up with similar findings, and further highlighted the importance of a sense of community ownership of the water supply scheme as a strong antecedent to community participation (Akbar et al. 2007).

\section{The utility-community partnership should be formalised and institutionalised}

Just like any other community-managed programmes, implementation of WSPs with participation of community members needs to be well institutionalised, in order to sustainably achieve their objectives. A study carried out in Sri Lanka, Pakistan and India found numerous good practices of community-managed schemes, but many of them were isolated and there was no evidence of mainstreaming (Sohail et al. 2001). An earlier study conducted in the same countries identified the need for an effective and continuously 'energised' partnership between the utility and the community members, rather than the 
former abdicating their responsibilities in service delivery. The partnership should be based on the key principles of (i) clarity of roles and responsibilities; (ii) accountability of actions; and (iii) performance improvement. Furthermore, the community leadership structures should play a central role in defining an appropriate strategy and plan for implementing O\&Mrelated tasks (Cotton \& Tayler 2000).

The partnership between the utility and the community members needs to be formalised, possibly through signing a Memorandum of Understanding (MoU) (Cotton \& Tayler 2000; Sohail et al. 2001; Sohail et al. 2005). The following key activities should be carried out with caretakers in the communities, as a build-up to developing a workable $\mathrm{MoU}$ for O\&M between the community and the water utility (Cotton \& Tayler 2000):

- Through discussions, ensure the caretakers understand the O\&M requirements of different infrastructure options, their implications to service improvements, and likely extent of utility’s involvement;

- Assess the caretakers’ perceptions of the nature and frequency of activities they believe to be necessary for achieving their desired levels of service;

- Explore the caretakers’ capacity and willingness to participate in O\&M activities;

- Guide the community members to make plans for O\&M;

- Ensure there are mechanisms for the caretakers to be accountable to their communities, which are set out in the MoU.

For the partnership to be effective, community-managed O\&M strategies and plans should be mainstreamed in the utility’s corporate strategy/plans, budgets and performance management systems. The utility should develop WSPs that are effectual but simple enough for the community members to operate. As already discussed, there will certainly be the need to 
develop the skills of the relevant members of the community. A monitoring and evaluation system should be set up, involving both the service provider and community structures. Other factors that enhance the effectiveness of the partnerships are: (i) level of community awareness of O\&M issues, (ii) extent of user care for facilities, (iii) local capacity for action, (iv) community leadership; and (v) commitment and responsiveness of the service provider (Cotton \& Tayler 2000; Sohail et al. 2001; Sohail et al. 2005).

The partnership should be facilitated with an adequate and comprehensive documentation system, which uses simple monitoring tools that are appropriate and comprehensible to the caretakers (Mahmud et al. 2007), as discussed in more detail in the next section. Research carried out in Indonesia shows that lack of communication between the water utility and the community members is one of the most critical barriers to water service delivery to lowincome urban settlements (Zakaria 2009). Close working relationships between the community and the water utility are necessary to provide continuous technical support for effective water quality management, which requires higher level skills compared to other O\&M tasks (Arsenic Policy Support Unit [APSU] 2006).

\section{Participatory approaches for developing bespoke community-managed WSPs}

In most cases, community-managed water supply schemes will not have people with the necessary skills to develop tailor-made WSPs without external assistance. Hence, WHO proposed two approaches for developing community-managed WSPs: generic WSPs for particular technologies developed for a region or country; or producing guidelines that support local development of WSPs, illustrated by practical examples. The use of model or guided plans is suitable for community-managed water supplies, which requires limited technical expertise, and significantly reduces the costs and complexity of implementing the 
WSPs (Howard et al. 2005; Mahmud et al. 2007). Even so, these guided plans will most

likely be a technical format, which caretakers and other community members may not

understand. It is therefore advisable that caretakers and other relevant community members

be guided and facilitated to develop tailor-made WSPs, taking them through a participatory

process of (i) assessing the hazardous events which could affect the water supply; (ii)

developing the control measures for effective water safety management; (iii) how to monitor

compliance; (iv) coming up with corrective measures to be taken; and (v) verifying the

effectiveness of the whole supply system (APSU 2006; Mahmud et al. 2007; Tearfund 2011).

Table 1 shows an example of a participatory approach adopted by Tearfund in South Sudan.

Table 1: Participatory approaches for forming a community-managed WSP (adapted from Tearfund 2011)

\begin{tabular}{|c|c|c|}
\hline & Participatory exercises & $\begin{array}{l}\text { Expected key } \\
\text { output(s) }\end{array}$ \\
\hline $\begin{array}{l}\text { Stage 1- } \\
\text { Describing the } \\
\text { water supply } \\
\text { system }\end{array}$ & $\begin{array}{l}\text { a. Transect walks - community members' journey through } \\
\text { their community and the surrounding areas, visiting the } \\
\text { water sources used throughout the year, both for } \\
\text { potable/domestic and productive use } \\
\text { b. Community mapping - used for representing the } \\
\text { findings on paper, and as a tool of 'negotiation' about } \\
\text { the accuracy of the map }\end{array}$ & $\begin{array}{l}\text { A visual display of } \\
\text { the water supply } \\
\text { system using } \\
\text { pictures, drawings or } \\
\text { photographs }\end{array}$ \\
\hline $\begin{array}{l}\text { Stage } 2 \text { - } \\
\text { Analysing the } \\
\text { water supply } \\
\text { system to } \\
\text { identify } \\
\text { hazards \& } \\
\text { come up with } \\
\text { control } \\
\text { measures }\end{array}$ & $\begin{array}{l}\text { a. Using the visual description of the water supply system } \\
\text { developed in Stage } 1 \text { to discuss, first in small groups, } \\
\text { and then in a plenary session, the possible problems that } \\
\text { could stop them getting clean water (hazards) } \\
\text { b. Brainstorming session to prioritise identified } \\
\text { problematic or vulnerable areas (risk prioritisation) at } \\
\text { the various stages of the water supply system, to be } \\
\text { mapped on the visual diagram } \\
\text { c. Group discussions to come up with a chart of good } \\
\text { things that help to keep the water clean, ranking the } \\
\text { activities according to how easy they are to accomplish }\end{array}$ & $\begin{array}{l}\text { Existing and } \\
\text { potential hazards } \\
\text { and control } \\
\text { measures developed } \\
\text { by the community } \\
\text { members, with some } \\
\text { guidance from } \\
\text { knowledgeable } \\
\text { people }\end{array}$ \\
\hline $\begin{array}{l}\text { Stage } 3 \text { - } \\
\text { Establishing a } \\
\text { regime of } \\
\text { monitoring } \\
\text { and preventive } \\
\text { maintenance }\end{array}$ & $\begin{array}{l}\text { a. A facilitated discussion on who does what, and when, } \\
\text { taking into consideration gender considerations, and } \\
\text { based on the control measures identified in Stage } 2 \\
\text { b. Agreement on the roles and responsibilities amongst the } \\
\text { community members }\end{array}$ & $\begin{array}{l}\text { Monitoring and } \\
\text { preventive } \\
\text { maintenance chart } \\
\text { specifying who will } \\
\text { do what and how } \\
\text { frequently }\end{array}$ \\
\hline $\begin{array}{l}\text { Stage } 4- \\
\text { Managing the } \\
\text { WSPs and } \\
\text { controlling }\end{array}$ & $\begin{array}{l}\text { a. Setting up community self-evaluation events on a } \\
\text { regular basis, e.g. simple knowledge, attitude and } \\
\text { practice (KAP) surveys to evaluate the impact of WSPs } \\
\text { b. Involving the community leadership such as religious }\end{array}$ & $\begin{array}{l}\text { An agreed } \\
\text { community- } \\
\text { managed regular } \\
\text { evaluation plan }\end{array}$ \\
\hline
\end{tabular}




\begin{tabular}{|l|l|l|}
\hline incidents & $\begin{array}{l}\text { and civic leaders in the overall evaluation of the WSP } \\
\text { implementation, and assess the overall impact on water } \\
\text { safety management }\end{array}$ & $\begin{array}{l}\text { supervised by the } \\
\text { community water } \\
\text { committees }\end{array}$ \\
\hline
\end{tabular}

As a prerequisite, it is important that the community members are guided to understand what constitutes safe drinking water; what WSPs are; and how they relate to the overall objectives of ensuring safe drinking water and overall public health (Mahmud et al. 2007; Tearfund 2011). These capacity development sessions should be conducted using participatory approaches. For instance, in South Sudan, small groups were asked to tell water-related picture stories about the communities, followed by plenary discussions (Tearfund 2011). Various practical and participatory approaches could then be employed to take the caretakers and community members through the various stages of the WSPs. In Bangladesh, a series of training workshops were organised for the community members, with refresher courses specifically tailored for water point management committees and caretakers (Mahmud et al. 2007).

The key expected outcomes of the participatory activities are (Tearfund 2011):

-Various groups of the community become more aware of the burden of fetching water, illness associated with bad water, and impact on overall wellbeing; this will in turn lead to the community members jointly agreeing on a goal for maintaining safe water quality.

- Community members are able to describe their water supply system and its various components.

- Community members become familiar with potential contamination hazards; identify control measures; and become aware that all community members (men, women and children) have a role in maintaining safe water quality. 
- All key stakeholders agree to a plan for implementing the WSPs, and come up with agreed reference documentation of the roles and responsibilities.

Tearfund adapted the participatory approach shown in Table 1 to suit the local conditions in Afghanistan. The process with Afghanistan communities, which have a higher literacy rate than South Sudan communities, was in the form of simplified matrices, with more written instructions. It is important that the design of community-based WSPs is flexible, so as to match with the contextual conditions (Tearfund 2011). Similar participatory approaches were applied in pilot projects for implementing community-managed WSPs for various water supply technologies in Bangladesh, supported by the Arsenic Policy Support Unit (APSU) and local/international non-governmental organisations (NGOs) (APSU 2006; Mahmud et al, 2007; Tearfund 2011). These pilot programmes underscored the importance of capacity development of the caretakers, who were considered the vanguard of implementing community-based WSPs. Hence, emphasis was placed on the caretaker selection process, before they could be trained in generic O\&M, hygiene promotion, and specific guidance in implementation of WSPs (Mahmud et al. 2007; Tearfund 2011).

Feedback received from the pilot studies conducted in Bangladesh showed that the simplified monitoring tools worked reasonably well, which enabled community committees and other members to get more engaged in monitoring and managing water safety (APSU 2006; Mahmud et al. 2007; Tearfund 2011). The pilot projects registered consistent reductions in sanitary risk, and improvements in microbial quality (Mahmud et al. 2007; Tearfund 2011). In these pilot projects, it was found that involving existing water user committees to supervise and cross-check the care takers' activities, in essence creating a functioning surveillance system, is a key success factor in the effectiveness of the WSPs. Another 
important observation from the pilot projects is that there will most certainly be a need to adapt the monitoring tools to meet local conditions, ensuring that the key message is included (Mahmud et al. 2007).

\section{SUMMARY AND CONCLUSION}

The development and operationalisation of WSPs in the last decade has significantly contributed to progress achieved in increasing access to safe drinking water. There is an increasing amount of literature in the public domain on advances in applying WSPs in large, utility-managed distribution systems in developed countries. However, the pace of implementing WSPs in water distribution systems in cities of developing countries is slower, partly because of the huge challenges water utilities face in extending, operating and maintaining water services to unplanned, low-income urban settlements, which house over $50 \%$ of the urban population in some developing countries (Water and Sanitation Programme 2009). Yet, the shift to the use of WSPs is more important for small-scale water supplies in low-income urban settlements, where field-testing of water quality is less reliable due to inadequate resources; there is limited development of surveillance networks; and there are low staff skills (Tearfund 2011; Mahmud et al. 2007).

Most urban water utilities in developing countries lack the necessary 'software' skills to effectively implement WSPs in low-income settlements, and so, like other aspects of water service provision to the urban poor, community participation is increasingly being applied to plug the utilities' skills gaps. There are a few government and non-governmental agencies that have piloted implementation of community-managed WSPs, and have documented their experiences in countries such as Afghanistan, Bangladesh and South Sudan. This paper reviewed the various experiences and synthesised the good practices, for the benefit of water 
utilities in developing countries planning to implement community-based WSPs in lowincome urban settlements.

An important observation is that WSPs are an important component of the utility's O\&M system, which contributes to upholding the water distribution network's physical, hydraulic and water quality integrity (Alegre et al. 2010). Hence, WSPs will be implemented more effectively and easier in urban water utilities where generic O\&M systems are already institutionalised (Parkinson 2010; Tearfund 2011). Furthermore, water utilities with good O\&M systems and which are willing/able to work with user communities will be in a better position to provide capacity development and on-going support that is much needed by caretakers and water committee members in the low-income communities. Communitymanaged WSPs will be sustainable with a high level of community participation, and community members will have a high sense of the project ownership.

For WSPs to be sustainable, the water utility should keep an active overseeing role, and should formalise the partnership with the community members. The roles and responsibilities of the various parties should be mutually discussed, agreed and spelt out in a formal document, such as a Memorandum of Understanding (MoU). The community members should be guided and facilitated, through participatory approaches, to develop, from first principles, WSPs for the part of the distribution network serving the specific low-income urban settlement. This process will enable the water utility and relevant members of the community to develop simple tailor-made monitoring tools that are suitable for application by the local caretakers, with overall supervision by the community leaders. Feedback from various pilot studies in Afghanistan, Bangladesh and South Sudan showed that the simplified 
bespoke monitoring tools were rated highly by the communities implementing WSPs, which led to improvements in microbial quality of the water supply in their local areas.

As more experiences of implementing WSPs are availed in the public domain, water utilities in developing countries are increasingly adopting WSPs for managing the water safety of the water distribution networks in well-planned parts of the urban areas. However, there is currently scanty information that is documented on full-scale implementation of WSPs in informal settlements of urban areas. The documented pilot studies carried out in Afghanistan, Bangladesh and South Sudan provide a good starting point for water utilities that are currently in the process of developing community-managed WSPs for low-income urban settlements. There is need for water utilities and other agencies implementing WSPs in unplanned, informal settlements to document their experiences, so that other organisations do not have to reinvent the wheel.

\section{ACKNOWLEDGEMENTS}

The author would like to express his gratitude to Tearfund and other organisations who carried out and documented various pilot projects referred to in this paper, and to the anonymous reviewers who provided very useful suggestions for upgrading the first draft of this paper, which was presented at the $2^{\text {nd }}$ IWA Water Safety Conference in Kampala in November 2012.

\section{REFERENCES}

Akbar, H.M.D, Minnery, J.R., van Horen, B. \& Smith, P. 2007 Community water supply for the urban poor in developing countries: The case of Dhaka, Bangladesh. Habitat International 31, 24-35. 
Alegre, H., Pitchers, R., Saegrov, S., Vreeburg, J., Bruaset, S. \& Rostum, J. 2010 Water quality - driven operation and maintenance of drinking water networks: Best Management Practice, Techneau WA5.6, European Commission, Brussels.

Arsenic Policy Support Unit (APSU) 2006 Water Safety Plans in Bangladesh: Experiences from Pilot Projects. Ministry of Local Government, Rural Development and Cooperatives, Dhaka, Bangladesh.

Cotton, A. \& Tayler, K. 2000 Services for the urban poor: 6. Operation and Maintenance. WEDC, Loughborough University, Loughborough.

Davis, J. \& Brikke, F. 1995 Making your water supply work - Operation and maintenance of small water supply systems. IRC International Water and Sanitation Centre, The Hague.

Esrey, S.A. 1996 Water, waste, and well-being: A multicountry study. Am. J. Epidemiol. 143(6), 608-623.

Godfrey, S. \& Howard, G. 2005a Water Safety Plans: Planning Water Safety Management for urban Piped Water Supplies in Developing Countries. WEDC, Loughborough University, Loughborough.

Godfrey, S. \& Howard, G. 2005b Water Safety Plans: Supporting Water Safety Management for Urban Piped Water Supplies in Developing Countries. WEDC, Loughborough University, Loughborough.

Government of India 2011 Operation and Maintenance Manual for Rural Water Supplies. Ministry of Rural Development and World Bank Water and Sanitation Programme, New Delhi.

Harvey, P.A. \& Reed, R.A. 2007 Community-managed water supplies in Africa: Sustainable or dispensable? Community Dev. J. 42(3), 365-378. 
Howard, G., Godfrey, S., Tibatemwa, S. \& Niwagaba, C. 2005 Water safety plans for piped water supplies in developing countries: A case study from Kampala, Uganda. Urban Water J. 2(3), 161-170.

Jayaratne, A. 2008 Water Safety Plans for O\&M improvements, presentation at the IWAWHO Water Safety Conference, 2010, available at (accessed on 29 December 2012) http://www.wsportal.org/templates/ld_templates/layout_33212.aspx?ObjectId=5083\&l ang=eng

Kayaga, S. 2009 Service Quality, Customer Satisfaction and Paying for Water Services: Empirical Findings from Urban Centres of Low-income Countries. VDM Verlag Dr Muller Aktiengesellschaft \& Co. KG, Saarbrucken, Germany.

Mahmud, S.G., Shamsuddin, A.J., Ahmed, M.F., Davidson, A., Deere, D. \& Howard, G. 2007 Development and implementation of water safety plans for small water supplies in Bangladesh: Benefits and lessons learnt. J. Water Health 5(4), 585-597.

McIntosh, A. 2003 Asian Water Supplies: Reaching the Urban Poor. Asian Development Bank and International Water Association, London.

Narayan, D. 1995. The contribution of people’s participation: Evidence from 121 rural water supply projects. Environmentally Sustainable Development Occasional Paper Series No.1. World Bank, Washington, DC.

Parkinson, J. 2010 Achieving improved water safety through better operation and maintenance practices. Drinking Water Safety International (April 2010), The Operation and Maintenance Network, IWA, London.

Sansom K. and Bos, A. (2008). Utility and non-state water service provision for the urban poor, International Journal of Water, 4(3/4), 290-303. 
Sohail, M., Cavill, S. \& Cotton, A.P. 2001 Operation, maintenance and sustainability of services for the urban poor: Findings, lessons learnt and case study summary and analysis. WEDC, Loughborough University, Loughborough.

Sohail, M., Cavill, S. \& Cotton, A.P. 2005 Sustainable operation and maintenance of urban infrastructure - myth or reality? J. Urban Plann. Dev. 131(1), 39-49.

Solo, T.M., Perez, E. \& Joyce, S. (1993). Constraints in providing water and sanitation services to the urban poor. WASH Technical Report No. 85, Water and Sanitation for Health Project, USAID, Washington DC.

Tearfund 2011 Water safety plans for communities: Guidance for adoption of water safety plans at community level. Tearfund, London.

Thompson, P. \& Majam, S. 2009 The development of generic water safety plans for small community water supply. Water Research Commission Report No TT 415/09, (by Umgeni Water), South Africa.

UN-HABITAT 2003 Slums of the world: The face of urban poverty in the new Millennium, UN-HABITAT, Nairobi.

UN-HABITAT 2010 UN-HABITAT Annual Report 2009. UN-HABITAT, Nairobi.

Uwejamomere, T. \& Northover, H. 2012 Are World Bank investments benefitting the urban poor? Improving the effectiveness of urban water and sanitation investments. WaterAid Discussion Paper.

Vairavamoorthy, K., Gorantiwar, S.D., Yan, J., Galgale, H.M., Mohamed-Mansoor, M.A. \& Mohan, S. 2006 Water Safety Plans: Book 3 - Risk Assessment of Contaminant Intrusion into Water Distribution Systems. WEDC, Loughborough University, Loughborough.

Waite, M. \& Ronche, E. (eds.) 2003 Drinking Water and Infectious Disease: Establishing the Links. CRC Press \& IWA Publishing, London. 
Water and Sanitation Program 2009 Guidance notes on services for the urban poor: A practical guide for improving water supply and sanitation services, Water and Sanitation Program, Washington, DC.

WaterAid 2011 Sustainability Framework. WaterAid, London.

WHO 2004 Guidelines for Drinking-Water Quality, $3^{\text {rd }}$ edition. WHO, Geneva.

WHO 2005 Water Safety Plans: Managing drinking-water quality from catchment to consumer. WHO, Geneva.

Zakaria, F. 2009 Assessing Pro-Poor Water Supply Programs in Jakarta. MSc Dissertation, University of Oxford.

First received 21 September 2012; accepted in revised form 3 February 2013. 